\title{
Edge effect on vascular epiphytic composition in a fragment of Atlantic Forest in northeastern Brazil
}

Randolpho Gonçalves Dias-Terceiro ${ }^{1^{*}}$, Gabriela Marques Peixoto ${ }^{2}$, Vitor Serrano Gomes ${ }^{3}$, Marcelo Costa Menezes ${ }^{4}$, Eudécio Carvalho Neco ${ }^{5}$, Tainá Sherlakyann Alves Pessoa ${ }^{6}$, Juliano Ricardo Fabricante ${ }^{7}$ and Manoel Bandeira Albuquerque

Received: August 16, 2014 Accepted: October 28, 2014

\begin{abstract}
Epiphytes are common in the canopy of temperate and tropical forests, where they substantially contribute to species diversity and to key ecosystem processes. However, little is known about the effects caused by deforestation on this group of species, especially in northeastern Brazil, an area experiencing intense anthropogenic pressure. This study aimed to evaluate the effect of environmental variables on the structure of assemblies of vascular epiphytes in a fragment of open ombrophilous forest, Areia, northeastern Brazil. Sixty $10 \times 10 \mathrm{~m}$ sampling plots were installed to cover different environments within the fragment. The relationship between environmental variables and species composition was evaluated by means of a generalized linear mixed model. The composition of assemblies of epiphytes differed with respect to distance from the edge and luminosity. In the study area, deforestation led to a change in the composition of epiphytic species both at the edge and the interior of the fragment.
\end{abstract}

Keywords: brejo de altitude, community ecology, epiphytism, environmental factors, forest fragmentation

Vascular epiphytes comprise around $10 \%$ of all known vascular plants, approximately 29,000 species, representing an important component of the biological diversity in tropical forests (Gentry \& Dodson 1987). This group of species plays an important role in the supply of nutrients in ecosystems, because they capture nutrients from the atmosphere (instead of the soil stock) in an efficient manner, making them available in the soil later, by means of the decomposition process of organic matter (Oliveira 2004). The contribution is particularly noticeable in the increased content of $\mathrm{P}, \mathrm{Ca}$, and $\mathrm{C}$ and decreased acidity (Pereira et al. 2005). Epiphytes are also an important source of nutrients for canopy animals, providing pollen, nectar, fruit, and water, and even, sites for nesting birds in some cases (Benzing 1990).
Because of the mandatory presence of phorophytes for their establishment, epiphytes are among the first life forms affected by deforestation (Sodhi et al. 2008). However, research on the major drivers of deforestation (e.g., forest fragmentation, edge effect) has focused on tree species (Meira-Neto \& Martins 2003) and little attention has been paid to their effect on epiphytes. Few studies evaluated the edge effect on vascular epiphytes (Bataghin et al. 2008, 2010; Köster et al. 2009; Bernardi \& Budke 2010; Bianchi \& Kersten 2014), and only one examined the edge effect on species composition (Bianchi \& Kersten 2014). In northeastern Brazil, no study has addressed the consequences of environmental changes caused by deforestation for the community of vascular epiphytes. Considering the importance of epiphytes in the ecosystem, investigating and assessing

\footnotetext{
${ }^{1}$ Laboratório de Ecologia de Vertebrados, Instituto Nacional de Pesquisas da Amazônia André Araújo, 2.936, Petrópolis, 69067-375, Manaus, AM, Brazil

${ }^{2}$ Laboratório de Herpetologia, Departamento de Ecologia e Sistemática, Universidade Federal da Paraíba, 58051-900, João Pessoa, PB, Brazil

${ }^{3}$ Departamento de Inspeção Ambiental, Secretaria de Meio Ambiente da Prefeitura de João Pessoa, 58053-900, João Pessoa, PB, Brazil

${ }^{4}$ Programa de Pós-Graduação em Desenvolvimento e Meio Ambiente, Centro de Ciências Exatas e da Natureza, Universidade Federal da Paraíba, 58051900 João Pessoa, PB, Brazil

${ }^{5}$ Programa de Pós-Graduação em Biologia, Departamento de Ecologia e Sistemática, Universidade Federal da Paraíba, 58051-900, João Pessoa, PB, Brazil ${ }^{6}$ Programa de Pós-Graduação em Ecologia e Evolução, Instituto de Ciências Ambientais, Químicas e Farmacêuticas, Universidade Federal de São Paulo, 09972-270, Diadema, SP, Brazil

${ }^{7}$ Centro de referência para recuperação de áreas degradadas, Universidade Federal do Vale do São Francisco, 56300-000, Petrolina, PE, Brazil

${ }^{8}$ Laboratório de Ecologia Vegetal, Departamento de Fitotecnia e Ciências Ambientais, Universidade Federal da Paraíba, 58.397-000, Areia, PB, Brazil

* Corresponding author:dias.terceiro@gmail.com
} 
the ecology of these species may be useful to understand and manage conservation.

Thus, this study aimed to evaluate the effect of environmental variables on the community structure of vascular epiphytes in a fragment of open ombrophilous forest, Paraíba, northeastern Brazil. The study area is located in the Center for Agricultural Sciences, Campus II, Federal University of Paraíba (UFPB), Areia ( $06^{\circ} 57^{\prime} 46^{\prime \prime} \mathrm{S}$ and $\left.35^{\circ} 41^{\prime} 31^{\prime \prime} \mathrm{W}\right)$, within the microregion of Brejo Paraibano. Local altitude is approximately $600 \mathrm{~m}$, the average annual temperature is $22^{\circ} \mathrm{C}$, the relative humidity is approximately $85 \%$, and the average annual rainfall is $1,450 \mathrm{~mm}$ (Mayo \& Fevereiro 1982). Because of the orographic effect of the eastern slope of the Borborema plateau, the vegetation is open ombrophilous forest, also named brejo de altitude (Veloso et al. 1991).

The study was conducted in a 50-ha fragment where 60 $10 \times 10 \mathrm{~m}$ sampling plots were installed, corresponding to $1.2 \%$ of the total fragment area. The distribution of plots was planned in order to cover six distinct geographical regions in the fragment: Upper Edge 1: the most peripheral region in the fragment, northbound; Upper Edge 2: region $20 \mathrm{~m}$ away from UE 1; Center of the Fragment 1: upper central region of the fragment; Center of the Fragment 2: lower central region of the fragment; Lower Edge 1: the most peripheral region in the fragment, southbound; and Lower Edge 2: region $20 \mathrm{~m}$ away from LE 1 . In each of the geographic regions, 10 plots were installed.

For the study, all shrub and tree individuals with a circumference at breast height $(\mathrm{CBH}) \geq 10 \mathrm{~cm}$ observed in each plot were analyzed. Within these sampling units, we determined all vascular epiphytic individuals. The material collected was herborized and subsequently registered in the herbarium JPB of UFPB and in the herbarium Jaime Coelho de Moraes of UFPB. The classification system follows APG III (2009) for angiosperms and Smith et al. (2006) for lycophytes and monilophytes.

To evaluate the effect of environmental variables on the composition and structure of epiphyte assemblies, the following variables were measured: (I) radiation index (RI): the radiation of each plot was measured with the aid of a light meter (Light Meter $\mathrm{LD}^{\circ}-209$ ); the relative luminosity index was calculated using the obtained values (Paiva \& Poggiani 2000); (II) distance from edge (DE): at each plot the distance from the closest edge was measured using a measuring tape; (III) density of shrub and tree individuals (DST): the total number of shrub and tree individuals with $\mathrm{CBH} \geq 10 \mathrm{~cm}$ was determined for each plot; and (IV) total basal area of shrub and tree individuals (BA): $\mathrm{CBH}$ of shrub and tree individuals with $\mathrm{CBH} \geq 10 \mathrm{~cm}$ was measured in each plot and the formula for basal area was applied (Mueller-Dombois \& Ellemberg 1974).

The species composition of vascular epiphytes in each plot was summed up through non-metric multidimensional scaling (NMDS). For these analyses, we selected only the plots where epiphytes and species with more than five individuals were present. The ranking was based on the dissimilarity between samples calculated by means of the Bray-Curtis index (Austin 2013).

The relation between environmental variables and species composition was evaluated using a generalized linear mixed model. None of the measured variables was correlated. We used geographic regions in the fragment (GR) as random variable. Therefore, our model was evaluated as follows: $\mathrm{NMDS}=a+b(\mathrm{RI})+b(\mathrm{DE})+b(\mathrm{DST})+b(\mathrm{BA})+$ $b(1 \mid \mathrm{GR})$. For statistical analyses, we used the software $R$ (R Core Team 2014).

In the survey, 1,277 shrub and tree individuals were sampled, with 65 phorophytic individuals. In total, 197 occurrences of vascular epiphytes were recorded, representing 12 species in 12 genera and five families (Tab. 1). For statisti$\mathrm{cal}$ analyses, seven species and 32 plots were used, because there were species with a low number of individuals and plots with no epiphytes.

The configuration produced on the NMDS axis was sufficient to explain $43.81 \%$ of the variance. The generalized linear mixed model using the NMDS axis (dependent variable) and environmental factors (independent variable) explained $27.79 \%$ of the variation in species composition $\left(\mathrm{NMDS}=-4.228^{-17}-3.573^{-1} \mathrm{RI}-3.294^{-1} \mathrm{DE}+2.615^{-1} \mathrm{DA}\right.$ $+5.363^{-2} \mathrm{AB} ; \chi^{2}=12.295 ; R^{2}=0.2779 ; P=0.01$ ). The variables that significantly contributed to the model were RI $(t=-2.195 ; P=0.03)$ and $\mathrm{DE}(t=2.05 ; P=0.05)$ (Tab. 2$)$.

The fragment studied here has a high degree of disturbance, considering there is no difference in the relationship between the distance from the edge and the incidence of radiation $\left(R^{2}=2.89^{-3} ; P=0.76\right)$. In some cases (especially in disturbed forests), even without this relation, other environmental factors (e.g., wind speed, humidity) may vary depending on the distance from the edge (Bataghin et al. 2008). Although there is no relation between luminosity and distance from the edge, the composition of epiphyte communities differed with regards to the gradient from edge to interior, something that suggests that other environmental factors acting on the periphery of the fragment (in addition to the variables under analysis) may have an effect on composition of epiphytes.

Studies conducted with vascular epiphytes showed no effect of distance from the edge on richness, abundance, or diversity index (Bataghin et al. 2008; 2010; Köster et al. 2009; Bernardi \& Budke 2010). Preliminary analyses also revealed the absence of an effect of distance from edge on the abundance $\left(R^{2}=3.15^{-3} ; P=0.75\right)$ and richness $\left(R^{2}=7.02^{-3} ; P=0.64\right)$ in the fragment focus of this study, reinforcing the idea that (independently of the location of study) the edge effect does not affect the abundance and richness of vascular epiphytes. However, a recent study has found differences in species composition along an edge-interior gradient (Bianchi \& Kersten 2014). Thus, although the distance from the edge has no effect on the richness and abundance of epiphytes, species occurring on 
Randolpho Gonçalves Dias-Terceiro, Gabriela Marques Peixoto, Vitor Serrano Gomes, Marcelo Costa Menezes, Eudécio Carvalho Neco, Tainá Sherlakyann Alves Pessoa, Juliano Ricardo Fabricante and Manoel Bandeira Albuquerque

Table 1. List of vascular epiphytic species collected in plots installed in the woods in the Center for Agricultural Sciences of UFPB. ${ }^{1}$ Species used for analysis (by having sufficient number of subjects); ${ }^{2}$ Species excluded from analysis (by having insufficient number of individuals); Voucher: registration number.

\begin{tabular}{|c|c|c|}
\hline Family/species & No Ind. & Voucher \\
\hline \multicolumn{3}{|l|}{ ARACEAE } \\
\hline Philodendron imbe Schott ex Endl. ${ }^{1}$ & 29 & $15,529^{*}$ \\
\hline \multicolumn{3}{|l|}{ BROMELIACEAE } \\
\hline Aechmea stelligera L.B. Sm. ${ }^{1}$ & 14 & $15,531^{*}$ \\
\hline Vriesea procera (Mart. ex Schult.f.) Wittm. ${ }^{1}$ & 7 & $15,528^{*}$ \\
\hline Tillandsia polystachya (L.) L. ${ }^{2}$ & 2 & $15,540^{*}$ \\
\hline \multicolumn{3}{|l|}{ CACTACEAE } \\
\hline Rhipsalis floccosa Salm-Dyck ex Pfeiff. ${ }^{1}$ & 22 & $14,431^{*}$ \\
\hline \multicolumn{3}{|l|}{ ORCHIDACEAE } \\
\hline Alatiglossum barbatum (Lindl.) Baptista ${ }^{2}$ & 1 & $14,428^{*}$ \\
\hline Catasetum macrocarpum Rich. ex Kunth ${ }^{2}$ & 2 & $15,536^{*}$ \\
\hline Epidendrum difformes Jacq. ${ }^{2}$ & 1 & $14,432^{*}$ \\
\hline Polystachya concreta (Jacq.) Garay \& H.R. Sweet ${ }^{2}$ & 1 & $14,429^{*}$ \\
\hline Vanilla schwackeana Hoehne ${ }^{1}$ & 6 & $15,535^{\star}$ \\
\hline \multicolumn{3}{|l|}{ POLYPODIACEAE } \\
\hline Microgramma vacciniifolia (Langsd. \& Fisch.) Copel. ${ }^{1}$ & 76 & $43,550^{* *}$ \\
\hline Pleopeltis macrocarpa (Bory ex Willd.) Kaulf. ${ }^{1}$ & 36 & $43,551^{* *}$ \\
\hline
\end{tabular}

* Species registered in the herbarium "Jaime Coelho de Moraes".

** Species registered in the herbarium "JPB".

Table 2. Results of fixed effects in generalized linear mixed model analyses for the analyzed fixed variables.

\begin{tabular}{lcccc}
\hline Fixed Effects & Estimate & Std. Error & t value & P value \\
\hline Intercept & $-4.228^{-17}$ & 1.577 & - & - \\
radiation index (RI) & $-3.573^{-1}$ & 1.628 & -2.195 & $0.03^{*}$ \\
distance from edge (DE) & $-3.294^{-1}$ & 1.607 & -2.05 & $0.05^{*}$ \\
density of shrub and tree individuals (DST) & $2.615^{-1}$ & 1.82 & 1.437 & 0.16 \\
total basal area of shrub and tree individuals (BA) & $5.363^{-2}$ & 1.826 & 0.294 \\
\hline
\end{tabular}

the edge are not the same as in the interior (or they do not occur with the same number of individuals). Some species were widely distributed along the entire edge-interior gradient, such as Microgramma vacciniifolia (Langsd. \& Fisch.) Copel., and Pleopeltis macrocarpa (Bory ex Willd.) Kaulf. Other species, in turn, were more strongly associated with edges such as Philodendron imbe Schott ex Endl. and Vriesea procera (Mart. ex Schult.f.) Wittm. The species Rhipsalis floccosa Salm-Dyck ex Pfeiff. was more strongly associated with distance from the edge. Luminosity can also cause the same effect, where areas with higher radiation may show a different composition (based on the abundance) when compared with areas with lower luminosity. Some species were widely distributed along the entire light gradient, such as M. vacciniifolia and P. macrocarpa. Aechmea stelligera L.B. Sm. was more strongly associated with high light intensity, whereas $P$. imbe and $V$. procera were more strongly associated with low luminosity.
Epiphytes are clearly sensitive to changes in environmental factors (e.g., altitude - Hietz \& Hietz-Seifert 1995) and anthropogenic disturbance (Wolf 2005). For the study area, the fragmentation caused by deforestation resulted in a change in species composition of epiphytes in relation to the edge and the interior of the fragment. Given the importance of epiphytes in the ecosystem, further studies must be conducted using replicable metrics, which can contribute to a conservation plan for these species in swamp areas in northeastern Brazil.

\section{References}

APG III. 2009. An update of the Angiosperm Phylogeny Group classification for the orders and families of flowering plants: APG III. Botanical Journal of the Linnean Society 161: 105-121.

Austin MP. 2013. Inconsistencies between theory and methodology: a recurrent problem in ordination studies. Journal of Vegetation Science 24: 251-268. 
Bataghin FA, Fiori A, Toppa RH. 2008. Efeito de borda sobre epífitas vasculares em Floresta Ombrófila Mista, Rio grande do sul, Brasil. O Mundo da saúde 32: 329-338.

Bataghin FA, Barros F, Pires JSR. 2010. Distribuição da comunidade de epífitas vasculares em sítios sob diferentes graus de perturbação na Floresta Nacional de Ipanema, São Paulo, Brasil. Revista Brasileira de Botânica 33: 501-512.

Benzing DH. 1990. Vascular epiphytes: general biology and related biota. Cambridge, Cambridge University Press.

Bernardi S, Budke JC. 2010. Estrutura da sinúsia epifítica e efeito de borda em uma área de transição entre Floresta Estacional Semidecídua e Floresta Ombrófila Mista. Floresta 40: 81-92.

Bianchi JS, Kersten RA. 2014. Edge effect on vascular epiphytes in a subtropical Atlantic Forest. Acta Botanica Brasilica 28: 120-126.

Gentry AH, Dodson CH. 1987. Diversity and biogeography of neotropical vascular epiphytes. Annals of Missouri Botanical Garden 74: 205-233.

Hietz P, Hietz-Seifert U. 1995. Composition and ecology of vascular epiphyte communities along an altitudinal gradient in central Veracruz, Mexico. Journal of Vegetation Science 6: 487-498.

Köster N, Friedrich K, Nieder J, Barthlott W. 2009. Conservation of Epiphyte Diversity in an Andean Landscape Transformed by Human Land Use. Conservation Biology 23: 911-919

Mayo SJ, Fevereiro VPB. 1982. Mata de Pau-Ferro - A pilot study of the Brejo Forest of Paraiba, Brazil. London, Bentham - Moxon Trust. Kew, Royal Botanic Gardens.
Meira-Neto JAA, Martins FR. 2003. Estrutura do sub-bosque herbáceoarbustivo da mata da silvicultura, uma Floresta Estacional Semidecidual no município de Viçosa - MG. Revista Árvore. 27: 459-471.

Mueller-Dombois D, Ellemberg H. 1974. Aims and Methods of Vegetation Ecology. New York, John Wiley \& Sons.

Oliveira RR. 2004. Importância das bromélias epífitas na ciclagem de nutrientes da Floresta Atlântica. Acta Botanica Brasilica 18: 793-799.

Paiva AV, Poggiani F. 2000. Crescimento de mudas de espécies arbóreas nativas plantadas no sub-bosque de um fragmento florestal. Scientia Forestalis 57: 141-151.

Pereira MG, Menezes LFT, Filho TBS, Silva AN. 2005. Propriedades químicas de solos sob Neoregelia cruenta (R. Grah) L.B. Smith na restinga da Marambaia, RJ. Floresta e Ambiente 12: 70-73.

R Core Team. 2014. R: A language and environment for statistical computing. R Foundation for Statistical Computing, Vienna, Austria. http:// www.R-project.org/.

Smith AR, Kreier HP, Haufler CH, Ranker TA, Schneider H. 2006. A classification for extant ferns. Taxon 55: 705-731.

Sodhi NS, Koh LP, Peh KSH, et al. 2008. Correlates of extinction proneness in tropical angiosperms. Diversity and Distributions 14: 1-10.

Veloso HP, Rangel-Filho ALRR, Lima JC. 1991. Classificação da vegetação brasileira adaptada a um sistema universal. Rio de Janeiro, IBGE.

Wolf JHD. 2005. The response of epiphytes to anthropogenic disturbance of pine-oak forests in the highlands of Chiapas, Mexico. Forest Ecology and Management 212: 376-393 